Katarzyna Klonowska

Wydział Pedagogiczny

Uniwersytet Warszawski

\title{
Paradygmat męskości w kontekście przemian obyczajowości seksualnej na przykładzie heteroseksualnej relacji sponsoringu seksualnego
}

Duża dynamika przemian obyczajowych skłania do namysłu nad koniecznością redefinicji klasycznego paradygmatu męskości. Mężczyzna i kategoria męskości coraz częściej pojawiają się w dyskursie akademickim, ze względu na występowanie nowych zjawisk dotyczących relacji międzyludzkich, będących odpowiedzią mężczyzn na zmiany socjokulturowe. Do takich relacji można zakwalifikować sponsoring seksualny. Celem artykułu jest refleksja nad urzeczywistnianiem męskości w relacjach heteroseksualnego sponsoringu seksualnego, w odniesieniu do istniejących teorii socjologicznych z uwzględnieniem analizy jakościowej anonsów zamieszczanych w Internecie przez mężczyzn - potencjalnych sponsorów, poszukujących partnerek do związku sponsorowanego.

\section{Męskość w kontekście przemian obyczajowych}

Obecnie zwraca się dużą uwagę na seksualizację mediów oraz przestrzeni publicznej i tabloidyzację seksualności. Podejście do seksualności człowieka uległo liberalizacji, seksualność $w$ różnych kontekstach staje się obecna właściwie w każdej dziedzinie życia. Mamy do czynienia z demokratyzacją pożądania i specyficzną "kulturą obnażania” (McNair 2004, s. 5). Środki masowego przekazu współtworzą obecną kulturę, w której publiczna nagość i nacechowane seksualnie spojrzenie są dozwolone jak nigdy dotąd $w$ historii i niejednokrotnie się do nich zachęca z powodu ich dużej wartości marketingowej.

Ze względu na różnorodne zmiany cywilizacyjne przemianom ulega także tradycyjnie postrzegany dualizm płci oraz wynikający z niego podział ról społecznych. Binaryzm płci, szczególnie widoczny dotychczas w obowiązujących stereotypach dotyczących właściwych cech świadczących o przynależności płciowej, 
zostaje obecnie poddany dyskusji. Tracą na aktualności stereotypy związane z płcią, które dotychczas były uproszczonym obrazem, mającym wartość poznawczą i porządkującym otaczającą rzeczywistość. W świadomości zbiorowej kobietom przypisuje się zwykle cechy ekspresyjne lub prospołeczne (np. dbałość o dobro innych ludzi), natomiast mężczyznom cechy instrumentalne lub sprawcze (np. asertywność lub sprawowanie kontroli) (Deaux, Kite 2002, s. 360). Obecnie różnice te ulegają zatarciu.

W naukach społecznych więcej miejsca przeznacza się na studia związane z przemianami kobiecości, a jako evergreen zmian paradygmatu płci od lat przytaczana jest myśl feministyczna. Męskość natomiast ujmowana jest zazwyczaj w kontekście kryzysu, pejoratywnych przeobrażeń będących odpowiedzią na rosnącą dominację kobiet. $\mathrm{W}$ literaturze wyróżnia się przyjmowanie różnych strategii mężczyzn wobec subiektywnie zagrożonej męskości, np. typy męskie scharakteryzowane przez Zbyszko Melosika (2002, s. 116-164): mężczyzna sukcesu, Rambo, macho, playboy oraz typy mieszane. W obliczu przemian mężczyzna, który dotychczas dzierżył władzę i skupiał cechy kulturowego dominatora, ostatecznie okazał się ofiarą systemu i człowiekiem zredukowanym. Odpowiedź na zmiany jest dwubiegunowa: z jednej strony dochodzi do głosu androgyniczność (koncepcja de-gendering) (Butler 2008), która charakteryzuje się harmonijnym połączeniem cech uważanych za męskie i żeńskie, lub też całkowitą rezygnacją z imperatywów dotyczących płciowości. $Z$ drugiej strony mamy do czynienia z hiperseksualizacją, w tym promowaniem zachowań promiskutywnych (Kurzępa 2005, s. 177) i nadmiernym prezentowaniem cech przypisanych stereotypowo czy też przez imperatywy kulturowe poszczególnym płciom. Analogicznie do powyższych stwierdzeń wymieniane są dwa dominujące paradygmaty męskości. Pierwszym z nich jest model tradycyjny, wywodzący się z tradycji judeochrześcijańskiej, w którym mężczyzna przedstawiany jest jako postać dominująca, łącząca cechy siły fizycznej i odporności psychicznej. Drugi model to męskość pojmowana nie androcentrycznie, a raczej androgynicznie. W tym kontekście jako ważną wartość zaznacza się partnerstwo płci oraz dążenie do szeroko pojętej samorealizacji (Arcimowicz 2008, s. 22). Przemiany męskości (szczególnie w Europie Zachodniej) zostały uznane za rzeczywisty, ciągły proces, na tyle dynamiczny i złożony, iż coraz większą popularnością wśród środowiska akademickiego cieszą się studia z zakresu męskości (men's studies).

Zmianom uległo również podejście do seksualności. Zaczęto doceniać seks o charakterze ludycznym i dionizyjskim (charakteryzujący się zabawą, swobodą i przyjemnością) z przewagą nad seksem $w$ wymiarze apollińskim, nakierowanym na harmonię i piękno (Lew-Starowicz 1986, s. 74). John Bancroft twierdzi, że jako społeczeństwo poradziliśmy sobie z tabuizacją seksu przedmałżeńskiego (przechodząc od modelu społeczeństwa restrykcyjnego do społeczeństwa permisywnego), ciągle natomiast nie akceptuje się pozamałżeńskiej aktywności seksualnej, przy nierównym statusie traktowania tego rodzaju aktywności kobiet i mężczyzn (Bancroft 2011, s. 223). Podczas gdy kobiety spotyka piętno i ostracyzm społeczny, pozamałżeńską aktywność seksualną mężczyzn traktuje się zdecydowanie 
łagodniej. Może to być jeden z czynników, które wpływają na decyzje mężczyzn o wchodzeniu w relacje oparte na sponsoringu seksualnym. Sponsoring seksualny rozumiany jest tu jako intymny związek między sponsorem i osobą sponsorowaną, funkcjonujący według konkretnie określonych (ustalonych obopólnie) zasad, polegający na finansowym lub rzeczowym wsparciu osoby atrakcyjnej seksualnie dla sponsora. Wartością handlową $\mathrm{w}$ związku sponsorowanym jest spełnianie konkretnych, osobistych oczekiwań (towarzyskich, seksualnych) sponsora przez osobę sponsorowaną. Ważną cechą sponsoringu jest zachowanie dyskrecji (często anonimowości) przez osoby pozostające $\mathrm{w}$ relacji sponsorowanej. Sponsoring można podzielić ze względu na orientację seksualną osób pozostających we wzajemnych relacjach. Zgodnie z takim kryterium można wyróżnić: sponsoring heteroseksualny, w którym najczęstsza konfiguracja partnerów to sponsor mężczyzna i osoba sponsorowana - młodsza od sponsora kobieta; rzadziej występuje relacja odwrotna. Drugi rodzaj, ze względu na orientację, to sponsoring homoseksualny, w którym sponsorem jest kobieta lub mężczyzna, a osobą sponsorowaną osoba tej samej płci co sponsor.

\section{Mężczyzna jako sponsor w heteroseksualnej relacji sponsoringu seksualnego}

Przemiany męskiego habitusu, uzależnione również od dużej dynamiki przemian obyczajowości seksualnej, mogą mieć swoje odzwierciedlenie w decyzjach mężczyzn dotyczących związków z kobietami, relacji seksualnych, np. w kontekście sponsoringu seksualnego. Pierre Bourdieu, odwołując się do socjobiologii, zaznacza, że mężczyzna jest ewolucyjnie zdeterminowany do dominacji. Maskulinizacja ciała męskiego (i feminizacja kobiecego) sprzyja zajmowaniu konkretnego miejsca w porządku socjalnym i płciowym. Człowiek angażuje się w różnego rodzaju "gry społeczne", co w przypadku mężczyzny oznacza rozwijanie męskości, np. poprzez politykę, interesy, naukę (Bourdieu 2004, s. 71). Mężczyzna posiada nieformalną, społeczną zgodę na dominującą pozycję opiekuna, który nadzoruje, osłania, ale i patrzy z góry na obiekt. Męskie spojrzenie na kobietę jest nośnikiem przemocy symbolicznej. Kobiecie natomiast przypisuje się pozycję „przedmiotu symbolicznego", o którego istnieniu stanowi „bycie widzianą". W związku z tym kobieta popada w stan ciągłej niepewności, a jej atrybutami powinny być: kobiecość, podległość, uważność, dyskrecja oraz wycofanie (Bourdieu 2004, s. 82).

Przywołując Bourdieu, zastanawiać się można, czy mężczyzna w kontrolowanej przez siebie relacji sponsoringu seksualnego (zupełnie innej niż w sankcjonowanym społecznie związku małżeńskim czy też coraz częściej sankcjonowanym związku kohabitacyjnym) (Slany 2010, s. 94-104) poprzez swoją nadrzędną pozycję w diadzie sponsorskiej, w sposób świadomy może urzeczywistniać swoją dominację, czy też wręcz przeciwnie, kontestując Bourdieu, mężczyzna jako sponsor może być pojmowany nie tylko jako sprawca przemocy symbolicznej, ale 
raczej jako człowiek, w kontekście humanistycznym, próbujący dostosować się/odnaleźć we współczesnej rzeczywistości. Zasadne jest zadanie pytania, czy nadrzędna pozycja mężczyzny sponsora jest pewną strategią urzeczywistniania męskiej dominacji.

Uwikłanie mężczyzn $w$ relacje sponsoringu seksualnego może wynikać $\mathrm{z}$ teorii z zakresu socjologii dotyczących strategii radzenia sobie wobec przemian społecznych i obyczajowych. Relację sponsoringu seksualnego można tłumaczyć giddensowską "teorią czystej relacji” (Giddens 2010, s. 124-137), której uczestników łączą więzi w takim tylko stopniu i na tak długo, na jaki zakres osoby nią związane decydują się poprzez jasno zawartą umowę. Według innej koncepcji funkcjonowanie mężczyzn w relacjach sponsorowanych może być swego rodzaju "upluszowieniem ryzyka" (Szlendak 2005, s. 250). Mężczyzna jako osoba dominująca w związku sponsorskim (z racji bycia nabywcą oferowanych usług) pozbawia samego siebie konieczności podejmowania ryzyka związanego ze standardowym poszukiwaniem kobiety (przede wszystkim jest zabezpieczony przed podejmowaniem ryzyka emocjonalnego). Istotna w odniesieniu do sponsoringu seksualnego może być również stworzona przez Baumana „kategoria turysty”, według której mężczyzna może być postrzegany jako kolekcjoner wrażeń i pozamaterialnych doznań (Bauman 2000, s. 133-153).

Co o swoich wyborach mówią sami mężczyźni sponsorzy? Chcąc uzyskać odpowiedzi na pytania dotyczące mężczyzn funkcjonujących w związkach o charakterze sponsoringu seksualnego, dokonano analizy anonsów internetowych zamieszczanych przez mężczyzn na portalu www.sponsoraszukam.pl. Analizie poddano 417 anonsów zamieszczanych przez mężczyzn w lutym 2014 roku. Poniżej przedstawione zostaną ogólne wnioski, jakich dostarczyło niniejsze badanie.

Ważnym aspektem analizy wyników badań była świadomość, że informacje zawarte $\mathrm{w}$ anonsach, ze względu na pewnego rodzaju wartość marketingową, nie muszą być prawdziwe. Anonsodawcy mogli z pełną świadomością zamieszczać informacje niezgodne ze stanem realnym, ponieważ anons pełnił funkcję autoreklamy i powodzenie znalezienia atrakcyjnej subiektywnie partnerki mogło zależeć przede wszystkim od sposobu przedstawienia własnej osoby. W związku $\mathrm{z}$ tym warto zaznaczyć, że przedstawione $\mathrm{w}$ anonsach tzw. „jja idealne" może być opozycyjne do "ja realnego" sponsorów, czemu mogło sprzyjać również poczucie bezwzględnej anonimowości w sieci. Jest to jednak tylko swego rodzaju hipoteza, co do potwierdzenia której nie ma pewności, w związku z czym nie można kwestionować prawdziwości wypowiedzi, a pozyskane dane należy traktować jako prawdziwe.

Anonse różniły się pod względem zawartości merytorycznej, ponieważ mężczyźni mieli całkowitą dowolność $\mathrm{w}$ kwestii zamieszczania i publikowania wszelkich informacji. Wyodrębniono jednak pewne elementy wspólne, które ostatecznie stały się przedmiotem analizy i dostarczyły wiedzy na temat trzech głównych komponentów budowania relacji sponsoringu seksualnego przez mężczyzn. Wnioski opisano z podziałem na trzy grupy powiązanych ze sobą aspektów sponsoringu: 
1. Wyobrażenia sponsora dotyczące związku.

2. Budowanie własnego wizerunku w anonsach.

3. Wymagania sponsora względem poszukiwanej kobiety.

Ad 1. Wyobrażenia sponsora dotyczące związku odnosiły się do kwestii związanych z miejscem/miastem spotkań sponsora z osobą sponsorowaną. Okazało się, że sponsoring jest obecny w różnych miastach Polski (o różnej wielkości oraz liczbie ludności), ale najbardziej popularny jest w miastach wojewódzkich, stanowiących konglomeracje przemysłowe oraz duże ośrodki akademickie. Najwięcej propozycji sponsoringu dotyczyło Warszawy. Stolicę jako miejsce budowania relacji sponsorskich określono w 40\% anonsów. Trzeba zaznaczyć jednak pewną elastyczność, o której w anonsach wspomniało wielu potencjalnych sponsorów: "Chcę nawiązać znajomość na zasadach, które ustalą razem obie strony. Myślę, że nie musi się ona ograniczać do płaszczyzny łóżka”. „Wszelkich ustaleń dokonamy bezpośrednio drogą mailową lub na spotkaniu w cztery oczy”.

Ważna jest również kwestia samego nazewnictwa sponsoringu przez sponsorów. W anonsach stosowano nazwy eufemistyczne: związek, układ, relacja, znajomość, przyjacielski układ, znajomość typu 'friends with benefits', wzajemnie korzystny układ koleżeński, znajomość z aspektem finansowym w tle, dyskretna znajomość, bliska relacja, spotkania sponsorowane, spotkania intymne, stała znajomość sponsorowana, niezobowiązujące spotkania, relacja wiadomego typu, a nawet coaching. Także samo wynagrodzenie mężczyźni określali nie wprost: gratyfikacja finansowa, kieszonkowe, miesięczne stypendium, stała pensja, ryczałt miesięczny, miesięczna pensja, pomoc finansowa; sponsorzy składali również deklaracje: wynagrodzę Cię, będę pomagał finansowo.

Problem wynagrodzenia obejmował jego formę oraz wysokość. Sponsorzy w większości przypadków preferowali wypłatę wynagrodzenia za każde spotkanie, a jego kwota wahała się od najniższej: 200 zł, do najwyższej: 2000-3000 zł. Kwota wynagrodzenia miesięcznego określana w anonsach wynosiła od 2000 do 12000 zł. W zdecydowanie mniejszej części anonsów jako formę wynagrodzenia mężczyźni zaoferowali „mieszkanie za towarzystwo”. Dla sponsorów bardzo ważna okazała się kwestia dyskrecji, której bezwzględnie wymagają i którą sami zapewniają. Ze względu na pragnienie zachowania anonimowości (co łączy się z dyskrecją) niewielu mężczyzn zdecydowało się na zamieszczenie obok anonsu swojej fotografii. Bojąc się ryzyka rozpoznania, tylko pojedynczy mężczyźni podpisali swoje anonse imieniem, a tylko w nielicznych przypadkach podali swój znak zodiaku. Niewielu mężczyzn zwróciło w anonsach uwagę na kwestię higieny, tylko pojedynczy sponsorzy poruszali temat zabezpieczenia kontaktów seksualnych i zdrowia. Wielu mężczyzn zaznaczało również, że nie szuka kryptoprostytucji, pisali często „profesjonalistkom dziękuję”, co wyraźnie wskazuje na to, że sami sponsorzy nie identyfikują sponsoringu z prostytucją. Jest to spowodowane prawdopodobnie częstym poszukiwaniem przez sponsora w związku sponsorowanym przyjaźni, zrozumienia oraz więzi emocjonalnych, a nie tylko mechanicznego seksu. 
Ad 2. Budowanie własnego wizerunku w anonsach odbywało się za sprawą opisu własnej osoby przez sponsora. Podstawą autoprezentacji w anonsach był opis wyglądu fizycznego oraz swoich cech osobowości/charakteru. Większość mężczyzn nie zdradziła w anonsach rodzaju/poziomu swojego wykształcenia, natomiast wśród 79 osób, które się na to zdecydowały, przeważali mężczyźni z wykształceniem wyższym lub podyplomowym. Również zdecydowana mniejszość sponsorów określiła swój zawód $(24,5 \%)$ oraz stan cywilny $(29 \%)$. Wśród osób, które się na to zdecydowały, niemal w równowadze znajdowali się mężczyźni żonaci lub single, prezentujący zawód przedsiębiorcy lub biznesmena. Mężczyźni niechętnie pisali w anonsach o swojej sytuacji rodzinnej, żaden z nich nie napisał nic o posiadanych dzieciach.

Przyczyny poszukiwania partnerek do związku sponsorowanego łączą w sobie elementy teorii socjologicznych przytoczonych we wcześniejszej części artykułu. W wielu przypadkach mężczyźni tłumaczyli powody swojej decyzji o zostaniu sponsorem, a były to: chęć urozmaicenia życia i przeżycia przygody; pragnienie spełnienia określonych fantazji seksualnych lub niezaspokojone potrzeby seksualne; monotonia w małżeństwie; samotność, zapracowanie, brak czasu na standardowe poznawanie kobiet; zniechęcenie miłością po rozstaniu z partnerką.

Ad 3. Trzeci komponent anonsu stanowiły wymagania sponsora względem poszukiwanej kobiety. W tym przypadku sponsorzy formułowali szczegółowe wymagania co do wyglądu fizycznego, wieku oraz cech osobowości potencjalnej partnerki relacji sponsorowanej. Okazało się, że w anonsie tak naprawdę najmniej miejsca zajmowała osoba potencjalnej partnerki. W anonsach mężczyźni skupiali się raczej na sobie lub opisie zasad, jakie preferują w związku sponsorskim. Żaden z mężczyzn nie określił dokładnie pożądanego wieku poszukiwanej kobiety. Podawano jedynie pewne ramy wiekowe, które trudno powiązać i ze sobą porównywać, ze względu na bliższą niedookreśloność. Na podstawie zebranych danych powstał jednak obraz górnej granicy wieku kobiet akceptowanej przez sponsorów. Najczęściej poszukiwano kobiet, które nie ukończyły jeszcze 30 roku życia. Wiek najmłodszej poszukiwanej kobiety jeden ze sponsorów określił na 16-20 lat, natomiast najstarsza potencjalna partnerka miała mieć między 45-60 lat. Prawie $50 \%$ mężczyzn opisało natomiast $\mathrm{w}$ anonsach swoje wymagania względem wyglądu fizycznego kobiety, 60\% określiło swoje preferencje w zakresie cech osobowości. Ważną, często wymienianą cechą, pożądaną wśród poszukiwanych kobiet (obok atrakcyjności fizycznej), była inteligencja.

\section{Mity dotyczące sponsoringu seksualnego}

Na podstawie analizy anonsów odmitologizowaniu uległo wyobrażenie osoby sponsora. W świadomości społecznej jest to najczęściej mężczyzna w średnim wieku, który opłaca kobietę zdecydowanie młodszą od siebie, a osią związku jest seks. Analizowane dane pokazały, że sponsorzy to najczęściej mężczyźni między 
30 a 40 rokiem życia (taki wiek wskazała niemal połowa mężczyzn określających swój wiek) i chociaż najczęściej poszukiwano kobiet do 30 roku życia, to w licznych przypadkach poszukiwano również kobiet starszych, a najwyższą akceptowaną granicę wieku jeden ze sponsorów określił na przedział między 45 a 60 lat. Niniejsze badania pozwoliły również w części zdemaskować mit społeczny, który głosi, że w relacjach sponsoringu seksualnego najczęściej funkcjonują studentki. Okazało się, że stosunkowo niewielu, bo mniej niż 25\% (N=417) mężczyzn, poszukuje do relacji sponsorowanej studentek.

Temat sponsoringu stanowi duże wyzwanie badawcze. Jest to zjawisko wielowymiarowe, bardzo trudno o jego wyczerpujące i ostateczne opracowanie. Na podstawie niniejszych badań nasuwa się wniosek, że sponsoring ma charakter jasno sprecyzowanej umowy między dwojgiem świadomych ludzi. Widoczna jest w tym aspekcie wyraźna analogia do opisanej przez Giddensa teorii czystej relacji, według której związki między ludźmi przybierają luźną postać i wiążą partnerów relacji tak długo i tylko do tego stopnia, na jaki partnerzy relacji się godzą. Są to związki podtrzymywane do momentu, w którym bliski kontakt jest źródłem satysfakcji, np. emocjonalnej. Według Giddensa (2010, s. 124-137) taki związek charakteryzuje się obopólnym zaufaniem, które umożliwia osiągnięcie intymności, a po ustaniu relacji partnerzy nie mają wobec siebie żadnych zobowiązań, ponieważ poprzez funkcjonowanie w związku zrealizowali swój doraźny interes.

Jeśli by sponsoring sprowadzić do tak pojmowanego związku, to wydaje się on stanowić relację, która nie powinna inicjować dyskusji o podłożu moralno-etycznym. Uprawnione natomiast wydaje się zakwalifikowanie sponsoringu raczej jako niestandardowej relacji seksualnej czy jako jednego ze stylów życia, wybieranego przez sponsorów oraz osoby sponsorowane. Można skonstatować, że sponsoring seksualny jest świadomym wyborem oraz pewnego rodzaju odpowiedzią mężczyzn na obecną dynamikę zmian obyczajowych.

\section{Literatura:}

Arcimowicz K., 2008, Przemiany męskości w kulturze wspótczesnej [w:] Nowi mężczyźni? Zmieniajace się modele męskości we wspótczesnej Polsce, M. Fuszar (red.), Warszawa.

Bancroft J., 2011, Małżeństwo i wolne zwiazki [w:] Seksualność człowieka, Wrocław.

Bauman Z., 2000, O turystach i wtóczęgach, czyli o bohaterach $i$ ofiarach ponowoczesności [w:] Ponowoczesność jako źródto cierpień, Warszawa.

Bourdieu P., 2004, Męska dominacja, Warszawa.

Butler J., 2008, Uwikłani w płeć: feminizm i polityka tożsamości, Warszawa.

Deaux K., Kite M., 2002, Stereotypy ptci w: Kobiety i mężczyźni: odmienne spojrzenia na różnice, B. Wojciszke (red.), Gdańsk.

Giddens A., 2010, Nowoczesność $i$ tożsamość "Ja" i społeczeństwo w epoce późnej nowoczesności, Warszawa.

Kurzępa J. 2005, Młodzież pogranicza - „świnki”, czyli o prostytucji nieletnich, Kraków.

Lew-Starowicz Z., 1986, Stownik seksuologiczny, Warszawa. 
McNair B., 2004, Seks, demokratyzacja pożądania i media, czyli kultura pożądania, Warszawa.

Melosik Z., 2002, Kryzys męskości w kulturze wspótczesnej, Poznań.

Slany K., 2002 Alternatywne formy życia matżeńsko-rodzinnego w ponowoczesnym świecie, Kraków.

Szlendak T., 2005, Leniwe maskotki, rekiny na smyczy. W co kultura konsumpcyjna przemienita mężczyzn i kobiety, Warszawa.

\section{Summary}

The masculinity paradigm in the context of changes: heterosexual male sponsorship

The author of the article discusses basic assumptions of dominant version of masculinity in the era of sexualization. The article presents selected research findings illustrating the phenomenon of heterosexual male sponsorship.

Keywords

masculinity, sexuality, sponsoring, identity, sponsor

\section{Słowa kluczowe}

męskość, seksualność, sponsoring, tożsamość, sponsor 